\title{
GAMBARAN KADAR TRIASILGLISEROL DARAH PADA MAHASISWA ANGKATAN 2011 FAKULTAS KEDOKTERAN UNIVERSITAS SAM RATULANGI DENGAN INDEKS MASSA TUBUH $\geq 23 \mathrm{~kg} / \mathrm{m}^{2}$
}

\author{
${ }^{1}$ Juliana Benjamin \\ ${ }^{2}$ Yanti Mewo \\ ${ }^{2}$ Stefana Kaligis
}

\author{
${ }^{1}$ Kandidat Skripsi Fakultas Kedokteran Universitas Sam Ratulangi Manado \\ ${ }^{2}$ Bagian Biokimia Fakultas Kedokteran Universitas Sam Ratulangi Manado \\ Email: julianabenjamin92@gmail.com
}

\begin{abstract}
Triacylglycerol, a type of fat found in the blood on the body, is the result of the metabolism from food contains with fat and cholesterol. One of the factors that can increase the blood levels of triacylglycerol is obesity. This study's aim is to find out about the description of blood triacylglycerol levels at students year 2011 Faculty of Medicine Sam Ratulangi University with Body Mass Index $23 \mathrm{~kg} / \mathrm{m}^{2}$. This descriptive study, using puposive sampling method, was followed by 26 samples. The level of blood triasyglycerol from all samples in this study was $<150 \mathrm{mg} / \mathrm{dL}$. From the result can be concluded that the description of blood triacylglycerol levels at students Faculty of Medicine year 2011 Sam Ratulangi University with Body Mass Index $\geq 23 \mathrm{~kg} / \mathrm{m}^{2}$ is in the normal level.
\end{abstract}

Keywords: triacylglycerol, student year $2011, \mathrm{BMI} \geq 23 \mathrm{~kg} / \mathrm{m}^{2}$

\begin{abstract}
Abstrak: Triasilgliserol merupakan jenis lemak yang dapat ditemukan di dalam darah dan merupakan hasil uraian tubuh dan makanan yang mengandung lemak dan kolesterol yang dikonsumsi. Salah satu faktor yang dapat meningkatkan kadar triasilgliserol dalam darah adalah obesitas. Penelitian ini bertujuan untuk mendapatkan gambaran kadar triasilgliserol dalam darah pada mahasiswa angkatan 2011 Fakultas Kedokteran Universitas Sam Ratulangi dengan IMT $\geq 23 \mathrm{~kg} / \mathrm{m}^{2}$. Penelitian ini dilakukan pada bulan Oktober 2012 sampai dengan bulan Januari 2013. Jenis penelitian berupa penelitian deskriptif dengan metode purpossive sampling. Hasil penelitian menunjukkan dari 26 sampel semua memiliki kadar triasilgliserol darah $<150 \mathrm{mg} / \mathrm{dL}$. Dari hasil penelitian disimpulkan bahwa gambaran kadar triasilgiserol darah pada mahasiswa angkatan 2011 Fakultas Kedokteran Universitas Sam Ratulangi dengan indeks massa tubuh $\geq 23 \mathrm{~kg} / \mathrm{m}^{2}$ berada dalam batas normal.
\end{abstract}

Kata kunci: Triasilgliserol, mahasiswa angkatan 2011, IMT $\geq 23 \mathrm{~kg} / \mathrm{m}^{2}$.

Masalah gizi masih merupakan masalah kesehatan di berbagai belahan benua yang membutuhkan penanganan. Masalah gizi lebih adalah masalah gizi di negara maju, yang juga mulai terlihat di negara-negara berkembang, termasuk di Indonesia sebagai dampak keberhasilan di bidang ekonomi. ${ }^{1}$ Peningkatan kondisi sosial ekonomi memungkinkan perubahan gaya hidup salah satunya yaitu perubahan pola makan, terjadi pergeseran pola makan dari tinggi karbohidrat, tinggi serat dan rendah lemak menjadi pola makan yang rendah karbohidrat, rendah serat, tinggi lemak, serta tinggi protein. Hal inilah yang menyebabkan tingginya kasus penyakitpenyakit seperti penyakit jantung koroner (PJK), kanker kolon dan penyakit 
degeneratif lainnya di Indonesia. ${ }^{2}$

Menurut World Health Organization (WHO) tahun 1998 masalah gizi lebih atau obesitas adalah keadaan dimana terjadi akumulasi lemak yang berlebihan di dalam tubuh sehingga dapat mengganggu kesehatan. $^{3}$ Telah diterima secara luas bahwa lemak yang berlebihan dan obesitas merupakan faktor resiko terhadap diabetes, penyakit kardiovaskular dan dislipidemia. ${ }^{4}$ Selain itu obesitas juga berdampak pada fungsi pernapasan, psikologis, adaptasi sosial, diabetes melitus (DM), dan lain-lain. ${ }^{5}$

Obesitas masih merupakan masalah kesehatan yang memilliki angka kejadian yang tinggi, di Amerika Serikat 17,1\% anak-anak dan 32,2\% orang dewasa mengalami kenaikan berat badan dan obesitas, persentasenya meningkat dalam waktu singkat dimana pada laki-laki tahun 1999-2000 sebanyak 27,5\% tahun 20032004 meningkat menjadi 31,1\%, sedangkan pada wanita tidak ada kenaikan persentasi dimana tahun 1999-2000 sebanyak 33,4\% tahun 2003-2004 menjadi 33,2\%. ${ }^{6}$ Di negara Cina diperkirakan pada masyarakat Cina perkotaan $52 \%$ pria dan $42 \%$ wanita mengalami obesitas. $^{7}$

Di Indonesia berdasarkan hasil riset kesehatan daerah tahun 2010 Sulawesi Utara menempati urutan pertama dengan persentase obesitas sebanyak 29,5\%, disusul oleh Kepulauan Bangka Belitung 22,9\%, Gorontalo 22,1\% Kalimantan Timur 21,8\%\%, Kepulauan Riau 20,4\%, dan DKI Jakarta 20,0\%. Hasil riset kesehatan juga menunjukan bahwa kelebihan berat badan dan obesitas lebih sering didapati pada usia dewasa di atas 18 tahun di daerah perkotaan yaitu 10,5\% dibandingkan daerah pedesaan. ${ }^{8}$

Faktor risiko utama dari obesitas adalah perilaku konsumsi yang tidak sehat ditambah dengan konsumsi serat dan buah yang tidak mencukupi, merokok dan faktor aktivitas fisik sehari-hari yang kurang. ${ }^{9} \mathrm{Hal}$ ini menyebabkan terjadinya penumpukan lemak pada pembuluh darah. Salah satu komponen utamanya adalah triasilgliserol. Kenaikan triasilgliserol merupakan faktor risiko terhadap terjadinya penyakit jantung koroner. ${ }^{1}$ Penyakit jantung koroner merupakan jenis penyakit yang banyak menyerang penduduk Indonesia. Kondisi ini terjadi akibat penyempitan di dinding arteri koroner karena adanya endapan lemak dan kolesterol sehingga mengakibatkan suplai darah ke jantung menjadi terganggu. ${ }^{10}$

Penyakit jantung koroner masih menempati peringkat pertama penyebab kematian di Indonesia. ${ }^{11}$ Prevalensi nasional penyakit jantung adalah 7,2\% (berdasarkan diagnosis tenaga kesehatan dan gejala). Sulawesi Utara merupakan salah satu propinsi dengan prevalensi penyakit jantung koroner yang tertinggi di Indonesia. Hal ini disebabkan oleh aktivitas fisik masyarakat Sulawesi Utara yang rendah dimana Sulawesi Utara termasuk dari 16 provinsi dengan aktivitas terendah dengan prevalensi 48,2\%. Sulawesi Utara juga termasuk provinsi dengan sikap mengkonsumsi makanan yang beresiko seperti kafein, makanan manis dan penyedap. Setiap harinya orang Sulawesi Utara mengkonsumsi lemak sebanyak 7,3\% dalam satu kali makan atau lebih. ${ }^{12}$

Kadar kolesterol pada laki-laki dan perempuan mulai meningkat pada umur 20 tahun. ${ }^{10}$ Berdasarkan penelitian Nacher et al risiko penyakit jantung koroner mulai meningkat pada usia 18-39 tahun. ${ }^{13}$ Berdasarkan uraian di atas peneliti tertarik untuk mengangkat judul Gambaran triasilgliserol darah pada mahasiswa angkatan 2011 Fakultas Kedokteran Universitas Sam Ratulangi Dengan Indeks Massa Tubuh $\geq 23 \mathrm{~kg} / \mathrm{m}^{2}$.

\section{METODE PENELITIAN}

Penelitian ini bersifat deskriptif yang dilaksanakan di kampus kedokteran Universitas Sam Ratulangi dan pemeriksaan dilakukan di Laboratorium Prokita. Penelitian berlangsung dari bulan Oktober 2012 hingga Januari 2013. Populasi adalah mahasiswa angkatan 2011 dengan IMT $\geq 23$ $\mathrm{kg} / \mathrm{m}^{2}$ di Kampus Malalayang Manado. Pengambilan sampel dengan metode purpossive sampling dengan sampel terdiri dari 26 orang responden yang memenuhi 
kriteria inklusi yaitu bersedia menjadi responden, sehat, mahasiswa angkatan 2011 dan IMT $\geq 23 \mathrm{~kg} / \mathrm{m}^{2}$

Variabel bebas dalam penelitian ini yaitu $\mathrm{IMT} \geq 23 \mathrm{~kg} / \mathrm{m}^{2}$ dan variabel terikat yaitu kadar triasilgliserol dalam darah. Pengambilan responden dilakukan dengan membagikan kuesioner kemudian responden diukur tinggi badan (m) dan berat badan (kg) dan dihitung dengan rumus IMT, responden menandatangani informed consent dan kemudian diambil darahnya di fossa cubiti.

\section{HASIL PENELITIAN}

Penelitian yang dilakukan bertujuan untuk mengetahui gambaran kadar triasilgliserol darah pada mahasiswa angkatan 2011 Fakultas Kedokteran Universitas Sam Ratulangi. Responden penelitian sebanyak dua puluh enam responden, dengan indeks massa tubuh $\geq 23 \mathrm{~kg} / \mathrm{m}^{2}$.

Dilihat dari karakteristik jenis kelamin, laki-laki lebih banyak dari perempuan yaitu sebanyak 15 responden (57,7\%), sedangkan perempuan sebanyak 11 responden (42,3\%). Keterangan ini dapat dilihat pada Tabel 1.

Tabel 1. Sebaran responden menurut jenis kelamin

\begin{tabular}{lcc}
\hline Jenis Kelamin & $\begin{array}{c}\text { Jumlah } \\
\text { (n) }\end{array}$ & $\begin{array}{c}\text { Persentasi } \\
\text { (\%) }\end{array}$ \\
\hline Laki-laki & 15 & 57,7 \\
Perempuan & 1126 & 42,3 \\
Total & & 100 \\
\hline
\end{tabular}

Penelitian yang dilaksanakan di kampus kedokteran Universitas Sam Ratulangi, berdasarkan IMT dari 26 responden ditemukan IMT yang mendominasi adalah overweight yaitu sebanyak 13 responden (50\%) dan responden dengan IMT obese II menduduki jumlah yang paling sedikit yaitu sebanyak 3 responden yaitu (11,53\%). Keterangan ini dapat dilihat pada tabel dibawah ini.
Tabel 2. Sebaran responden menurut Indeks Massa Tubuh

\begin{tabular}{lcc}
\hline $\begin{array}{c}\text { Indeks Massa } \\
\text { Tubuh (Kg/m } \mathbf{2})\end{array}$ & $\begin{array}{c}\text { Jumlah } \\
\text { (n) }\end{array}$ & $\begin{array}{c}\text { Persentasi } \\
(\mathbf{\%})\end{array}$ \\
\hline Overweight 23-24,9 & 13 & 50 \\
Obese I 25-29,9 & 10 & 38,5 \\
Obese II $>30$ & 3 & 1,5 \\
Total & 26 & 100 \\
\hline
\end{tabular}

Dua puluh enam responden yang ada, ditemukan sebanyak 26 responden atau seluruh responden memiliki kadar triasilgliserol normal (100\%). Berdasarkan hasil triasilgliserol laki-laki memiliki kadar triasilgliserol darah lebih tinggi yaitu 66,67\% dan perempuan memiliki rata-rata kadar triasilgliserol darah 53,72\% (Tabel 3, 4).

Tabel 3. Sebaran responden laki-laki menurut Kadar triasilgliserol dalam darah. ${ }^{21}$

\begin{tabular}{lccc}
\hline $\begin{array}{l}\text { Kadar } \\
\text { triasilgliserol } \\
\text { (mg/dL) }\end{array}$ & $\begin{array}{c}\text { Jumlah } \\
\text { (n) }\end{array}$ & $\begin{array}{c}\text { Persentasi } \\
(\%)\end{array}$ & $\begin{array}{c}\text { Rata- } \\
\text { rata } \\
\text { TAG }\end{array}$ \\
\hline $\begin{array}{l}\text { Normal } \\
(<150)\end{array}$ & 15 & 57,7 & 66,67 \\
$\begin{array}{l}\text { Ambang batas } \\
\text { normal } \\
(151-199)\end{array}$ & 0 & 0 & 0 \\
$\begin{array}{l}\text { Triasilgliserol } \\
\text { tinggi }\end{array}$ & 0 & 0 & 0 \\
$\begin{array}{l}(200-499) \\
\text { Triasilgliserol } \\
\text { amat tinggi } \\
(500 \text { atau }>500)\end{array}$ & 0 & 0 & \\
\hline
\end{tabular}

Tabel 6. Sebaran responden perempuan menurut Kadar triasilgliserol dalam darah. ${ }^{21}$

\begin{tabular}{lccc}
\hline $\begin{array}{l}\text { Kadar } \\
\text { triasilgliserol } \\
\text { (mg/dL) }\end{array}$ & $\begin{array}{c}\text { Jumlah } \\
\text { (n) }\end{array}$ & $\begin{array}{c}\text { Persentasi } \\
(\%)\end{array}$ & $\begin{array}{c}\text { Rata- } \\
\text { rata } \\
\text { TAG }\end{array}$ \\
\hline $\begin{array}{l}\text { Normal } \\
(<150)\end{array}$ & 11 & 42,3 & 53,7 \\
$\begin{array}{l}\text { Ambang } \\
\text { normal } \\
(151-199)\end{array}$ & 0 & 0 & 0 \\
$\begin{array}{l}\text { Triasilgliserol } \\
\text { tinggi }\end{array}$ & 0 & 0 & 0 \\
$\begin{array}{l}\text { (200-499) } \\
\text { Triasilgliserol } \\
\text { amat tinggi } \\
(500 \text { atau }>500)\end{array}$ & 0 & 0 & \\
\hline
\end{tabular}




\section{BAHASAN}

Kadar triasilgliserol darah dari hasil didapatkan bahwa dari 26 responden dengan IMT $\geq 23 \mathrm{~kg} / \mathrm{m}^{2}$ semuanya memiliki kadar triasilgliserol normal. Hal ini cenderung menjelaskan bahwa kadar triasilgliserol darah tidak hanya bergantung pada IMT. Menurut teori pada keadaan obesitas terjadi penurunan adiponektin, adiponektin berkaitan dengan metabolisme triasilgliserol yaitu menurunkan akumulasi triasilgliserol pada otot polos dengan meningkatkan oksidasi asam lemak melalui aktivasi acetyl-CoA oxidate, carnitine palmitoytransferase-1 dan AMPkinase. Berdasarkan uraian diatas dapat dikatakan pada keadaan obesitas terjadi peningkatan triasilgliserol. ${ }^{14}$ Pada penelitian ini tidak ditemukan peningkatan triasilgliserol sehingga perlu dipikirkan faktor lain yang dapat menyebabkan peningkatan triasilgliserol. Maulana tahun 2007 mengatakan bahwa peningkatan triasilgliserol tidak hanya disebabkan oleh peningkatan berat badan tetapi dapat juga disebabkan oleh konsumsi alkohol, diet tinggi gula dan lemak serta gaya hidup tidak sehat lainnya, ${ }^{15}$ dapat juga disebabkan oleh faktor usia dan jenis kelamin. ${ }^{17,18}$ Berdasarkan uraian di atas selain faktor IMT kadar triasil-gliserol juga dipengaruhi oleh berbagai faktor seperti usia, aktifitas fisik dan pola makan.

Bachmid dalam penelitiannya pada 21 orang laki-laki berusia 40-59 tahun tahun 2011 mendapatkan terjadi peningkatan kadar triasilgliserol pada 11 responden membuktikan perbedaan kadar triasilgliserol pada usia tua dan usia muda. ${ }^{18}$ Newberger dan Kwiterovich dalam penelitiannya juga mengatakan bahwa pada usia yang lebih muda didapatkan profil lipid yang lebih baik dibanding usia yang lebih tua. ${ }^{16}$ Berdasarkan penelitian Patel umumnya tidak ditemukan peningkatan kadar triasilgliserol darah pada usia 30 tahun. ${ }^{15}$

Berdasarkan jenis kelamin ditemukan rata-rata triasilgliserol darah cenderung lebih tinggi pada laki-laki dibandingkan pada perempuan. Hal ini disebabkan adanya hormon estrogen pada perempuan yang berperan dalam menjaga tingkat kolesterol darah, ${ }^{15}$ dimana pada perempuan yang masih aktif menstruasi akan menekan lipoprotein A. ${ }^{19}$ Mieke tahun 2005 dalam penelitiannya pada kelompok usia lanjut mendapatkan hasil profil lipid menurut jenis kelamin didapatkan peningkatan triasilgliserol darah pada perempuaæ 200 $\mathrm{mg} / \mathrm{dL}$ lebih besar dibandingkan laki-laki. ${ }^{17}$ Hal ini disebabkan karena pada saat menopause akan terjadi penurunan estrogen. ${ }^{19}$

Selain usia, jenis kelamin dan aktivitas fisik dan pola makan juga memiliki kaitan erat dengan kadar triasilgliserol darah. Berdasarkan penelitian yang dilakukan oleh Widhalm 2004 di Austria yang menggunakan perbandingan kadar triasilgliserol sebelum dan sesudah diet dan berolahraga selama 3 minggu ternyata menunjukkan adanya perbedaan yang berarti antara kadar triasilgliserol sebelum dan sesudah berolahaga dan diet, dimana sesudah berolah raga dan diet kadar triasilgliserol menurun. $^{20}$ Pada saat sesorang melakukan aktivitas terjadi peningkatan kebutuhan glukosa, tetapi kadar insulin tidak meningkat, sebaliknya ambilan glukosa oleh jaringan otot pada saat istirahat membutuhkan insulin, hingga disebut insulin-dependen. $^{21}$ Insulin memfasilitasi glukosa memasuki sel lemak, glukosa dapat digunakan untuk mensintesis gliserol. Gliserol ini bersamaan dengan asam lemak dari hati, digunakan untuk mensintesis triasilgliserol dalam adiposit. Dengan mekanisme ini, insulin terlibat dalam mekanisme penumpukan triasilgliserol dalam sel lemak. $^{22}$

Selain aktivitas fisik, berdasarkan penelitian pemasukan berlebihan dari sumber energi yang berasal dari karbohidrat, lemak, protein maupun alkohol dapat meningkatkan kadar trasilgliserol dan kolesterol dalam darah. ${ }^{15}$ Peningkatan asupan karbohidrat akan meningkatkan kadar triasilgliserol karena bila asupan karbohidrat meningkat pembentukan piruvat dan asetil-KoA juga meningkat sehingga menyebabkan peningkatan pembentukan asam lemak secara de novo dari asetil-KoA. Asam-asam lemak ini akan mengalami esterifikasi dengan triosefosfat yang 
dihasilkan dari glikolisis menjadi triasilgliserol, sehingga terjadi peningkatan kadar triasilgliserol. Peningkatan asupan lemak juga akan meningkatkan kadar triasilgliserol. Hal ini karena hampir seluruh lemak yang terdapat dalam makanan $( \pm$ 90\%) terdapat dalam bentuk triasilgliserol. Triasilgliserol ini mengalami hidrolisis menjadi diasilgliserol, monoasilgliserol dan asam lemak bebas, selanjutnya asam lemak bebas ini akan mengalami esterifikasi dengan triosefosfat untuk membentuk triasilgliserol dengan demikian dapat dikatakan bahwa peningkatan asupan lemak akan menyebabkan peningkatan kadar triasilgliserol. $^{23}$

Pada penelitian ini ditemui adanya berbagai keterbatasan. Keterbatasan yang dihadapi antara lain kurangnya responden yang disebabkan oleh singkatnya waktu penelitian. Pada penelitian ini juga tidak dilakukan penelitian tentang pola makan dan aktivitas fisik.

\section{SIMPULAN}

Berdasarkan penelitian yang dilakukan dari Oktober 2012 sampai dengan Januari 2013, disimpulkan bahwa gambaran kadar triasilgliserol darah pada mahasiswa angkatan 2011 Fakultas Kedokteran Universitas Sam Ratulangi dengan IMI $23 \mathrm{~kg} / \mathrm{m}^{2}$ berada dalam batas normal.

\section{UCAPAN TERIMA KASIH}

Ucapan terima kasih disampaikan kepada dr. Diana S. Purwanto, MLabMed dan dr. Youla A. Assa, MKes, mahasiswa angakatan 2011 Fakultas Kedokteran Universitas Sam Ratulangi, Laboratorium Prokita dan pada semua pihak yang telah menumbuhkan ide atau gagasan dalam pemikiran penulis sehingga penulis bisa menyelesaikan artikel ini.

\section{DAFTAR PUSTAKA:}

1. Almatsier S. Prinsip Dasar Ilmu Gizi. Jakarta: Penerbit PT Gramedia Pustaka Utama, 2001; p.7-76.
2. Santoso A. Serat Pangan (Dietary Fiber) dan Manfaatnya bagi Kesehatan. Magistra. 2011; 75 Th. XXIII.

3. World Health Organization. Obesity: Preventing and managing the global epidemic. Report of a WHO Consultation on Obesity, Geneva, 3-5 June 1997. WHO/NUT/NCD/98.1. WHO: Geneva, 1998.

4. Chadha DS, Singh G, Kharbanda P, Vasdev V, Ganjoo RK. Anthropometric correlation of lipid profile in healthy aviators. Meta analysis or the published literature. IJASM. 2006;50;32-7.

5. Hariyanto D, Madiyono B, Sjarif DR, Sastroasmoro S. Hubungan ketebalan tunika intima media arteri carotis dengan obesitas pada remaja. Sari Pediatri. 2009;11;159-66.

6. Ogden CL, Carrol MD, Curtin LR, McDowell MA, Tabak CJ, Flegal KM. Prevalence of overweight and obesity in the United States, 1999-2004. Result of meta-analysis. JAMA. 2006;295;1549-55.

7. Shintawati R. Waist to hip ratio sebagai beterminan dari takikardia dan hipertensi pada wanita obese. Biosainstifika. 2008; hal 77-78.

8. Riset kesehatan daerah tahun 2010. Jakarta 1 Desember 2010. Hal 69-70.

9. Sartika RAD. Faktor resiko obesitas pada anak 5-15 tahun di Indonesia. Makara kesehatan. 2011;15;37-43.

10. Kasron. Kelainan dan penyakit jantung pencegahan serta pengobatannya. Yogyakarta: Nuha Medika, 2012; p.197, 206, 208.

11. Prakoso A. Panduan hidup sehat untuk mencegah penyakit jantung dan kematian mendadak. Dinamikamedia; 2011; hal 24, 46

12. Riset kesehatan daerah 2007. http:// www.scribd.com/doc/25886294/RiskesdalaporanNasional. Di unduh pada tanggal 6 September 2012.

13. Nacher ELN, Colangelo L, Beam C, Greenland P. Risk Factors for Coronary Heart Disease in Men 18 to 39 Years of Age. Ann Intern Med. 2001;134:433-439.

14. Setiawan M. Peran Resistensi Insulin, Adiponektin, dan Inflamasi pada Kejadian Dislipidemia Aterogenik.

15. Sulviana N. Analisis dan Hubungan Gaya Hidup dan Pola Makan dengan Kadar Lipid Darah dan Tekanan Darah pada 
Penderita Penyakit Jantung Koroner. Institut Pertanian Bogor. 2008. Hal 10, 14, 21-2.

16. Chandra T. Perbedaan Profil Lipid Remaja dengan Orang tua Berpenyakit Jantung Koroner dan Bukan Jantung Koroner. Universitas Diponegoro. Semarang. Thesis. Hal 79.

17. Khairani R, Sumeira M. Profil Lipid pada Penduduk Lanjut Usia di Jakarta, Universa Medicina. Oktober-Desember 2005, Vol.24. No 4.

18. Bachmid F. Gambaran Triasilgliserol Darah Pada Laki-laki Usia 40-59 Tahun ke atas dengan Indeks Massa Tubulæ 23 $\mathrm{kg} / \mathrm{m}^{2}$ [Skripsi]. Manado: Universitas Sam Ratulangi; 2012.

19. Mamat, Sudikno. Faktor-faktor yang Berhubungan dengan Kadar HDL (Analisis Data of The Indonesian Family Life Survey 2007/2008). Gizi Indon. 2010;32(2):143-149.

20. Anam. Pengaruh Intervensi Diet dan Olahraga dan Indeks Massa Tubuh
Kesegaran Jasmani, hsCRP dan Profil Lipid pada Anak Obesitas [Tesis]. Semarang: Universitas Diponegoro; 2010; Hal 67.

21. Yunir E, Soebardi S. Terapi Non Farmakologis Pada Diabetes Melitus. Dalam : Sudoyo AW, Setiyohadi B, Alwi I, Simabrata M, Setiati M, Editor. Buku Ajar Ilmu Penyakit Dalam. Jilid III edisi ke-5. Jakarta: Penerbit Interna Publishing, 2009; p.891-5.

22. Kurahmawati A. Hubungan Karakteristik (Usia dan Jenis Kelamin) dan Kadar Trigliserida Serum dengan Kejadian Kanker Kolorektal di RSUP dr.Kariadi Semarang [Skripsi]. Semarang: Universitas Diponegoro; 2012.

23. Hidayati SN, Hadi H, Lestariana W. Hubungan Asupan Zat Gizi dan Indeks Massa Tubuh dengan Hiperlipidemia padaMurid SLTP yang Obesitas Di Yogyakarta. Sari Pediatri. 2006;8(1):2531. 